\title{
Jurist-Diction
}

Volume 2 No. 1, Januari 2019

Article history: Submitted 2 December 2018; Accepted 6 January 2019; Available online 27 January 2019

\section{PERLINDUNGAN GURU TERKAIT TINDAKAN YANG DILAKUKAN PADA MURID YANG MELAKUKAN KENAKALAN}

\author{
Alfin Ersa Ardiansyah \\ Alfinersa22@yahoo.com \\ Universitas Airlangga
}

\begin{abstract}
In the decision of the Prabumulih District Court decided the case Number: 44 / Pid.Sus / 2015 / PN. $P B M$, the problem that occurred was teacher carries out disciplinary actions that aim to create a deterrent effect on students. When viewed from the aspect of criminal law, the actions taken by the teacher towards students in the form of scolding or giving reprimand, giving punishments such as menjewer, telling to stand up, and others, are formally against the law or can also be criminal acts but in criminal law are not always a person who has formally committed an unlawful act must be convicted, because there is a criminal offense set out in the criminal law law, namely 1). justification reason 2). forgiving reasons 3). reasons for the prosecution of prosecution. In the criminal law the teacher has not yet regulated the teacher who conducts the study. This analysis of teacher protection is an analysis of academic studies. The results of this analysis are expected to be a breakthrough in protecting the rights of teachers as educators without ignoring student rights.
\end{abstract}

Keywords: Student Delinquency; Limitation of Action for Educator.

\begin{abstract}
Abstrak
Dalam putusan Pengadilan Negeri Prabumulih memutus perkara Nomor: 44/Pid.Sus/2015/PN.Pbm, permasalahan yang terjadi adalah melakukan tindakan pendisiplinan yang bertujuan untuk membuat efek jera terhadap murid. Apabila dilihat dari aspek hukum pidana, perbuatan yang dilakukan guru terhadap murid berupa memarahi atau memberi teguran, memberi hukuman seperti menjewer, menyuruh berdiri, dan lain-lain, secara formil bersifat melawan hukum atau juga bisa merupakan tindak pidana namun dalam hukum pidana tidak selalu orang yang secara formal telah melakukan tindakan melawan hukum harus dipidana, karena terdapat alasan penghapus pidana yang diatur di dalam Kitab Undang-undang Hukum Pidana yaitu 1). alasan pembenar 2). alasan pemaaf 3). alasan penghapus penuntutan. Dalam Kitab Undang-Undang Hukum Pidana belum mengatur tentang guru yang melakukan pendisplinan yang bertujuan untuk mendidik. Analisis terhadap perlindungan guru ini merupakan analisis kajian akademis. Hasil dari analisis ini diharapkan dapat menjadi terobosan dalam melindungi hak-hak guru sebagai pendidik tanpa mengesampingkan hak-hak murid.
\end{abstract}

Kata Kunci: Kenakalan murid; Batasan Tindakan Tenaga Pendidik.

\section{Pendahuluan}

Bagi suatu negara, pendidikan memiliki peranan yang sangat penting untuk menciptakan perkembangan dan kemajuan untuk negara itu sendiri. Pendidikan tersebut tidak terlepas dari peran serta negara yang membantu untuk mewujudkan pendidikan dengan standar yang baik. 
Dalam Pasal 31 Undang-Undang Negara Republik Indonesia Tahun 1945 ayat (1) dijelaskan bahwa setiap Warga Negara Indonesia berhak untuk mendapatkan pendidikan tak terkecuali siapapun, dalam ayat (2) menjelaskan bahwa Warga Negara Indonesia wajib mengikuti pendidikan dasar yang dimana semua generasi muda Indonesia berhak untuk mendapatkan pendidikan dan negara wajib membiayai pendidikan setiap Warga Negara Indonesia, ayat (3) menjelaskan bahwa negara wajib mengusahakan dan juga menyelenggarakan sistem pendidikan nasional yang dapat mengajarkan pentingnya nilai moral sehingga bukan hanya mengedepankan mutu pendidikan saja tetapi juga tidak melupakan nilai moral didalamnya.

Pada Pasal 3 Undang-Undang No.20 Tahun 2003 tentang Sistem Pendidikan Nasional dijelaskan bahwa tujuan pendidikan nasional adalah mengembangkan potensi peserta didik agar menjadi manusia yang beriman dan bertakwa kepada Tuhan Yang Maha Esa, berakhlak mulia, sehat, berilmu, cakap, kreatif, mandiri, dan menjadi warga negara yang demokratis serta bertanggung jawab. Guru dan murid merupakan satu kesatuan yang mendukung terciptanya kegiatan belajar dan mengajar. Dalam masyarakat profesi guru adalah profesi yang di hormati karena mempunyai peran penting untuk mendidik dan membentuk kepribadian murid yang bertujuan untuk memajukan suatu bangsa serta meneruskan dan mengembangkan nilai-nilai hidup kepada anak didik.

Dunia pendidikan tidak terlepas dari peran guru yang mempunyai fungsi untuk membantu mencerdaskan setiap Warga Negara Indonesia. Peran guru bukan hanya sebatas untuk membantu mencerdaskan Warga Negara Indonesia saja, tetapi juga membantu untuk memberikan pelajaran moral yang menjadi hal dasar yang harus dimiliki oleh setiap Warga Negara Indonesia. Tugas seorang guru dalam menghadapi setiap murid harus ramah, sabar, menunjukkan pengertian, memberikan kepercayaan dan menciptakan suasana aman. Dalam proses pembelajaran mengenal adanya pemberian penghargaan (reward) dan hukuman (punishment) sebagai salah satu alat pendidikan. Pemberian hukuman (punishment) kepada murid yang melanggar aturan mempunyai tujuan untuk mendidik murid tersebut agar mengetahui norma dan aturan yang berlaku dalam dunia pendidikan. Hukuman yang diberikan kepada 
murid tersebut bisa dalam bentuk teguran lisan ataupun tertulis, bisa juga dalam bentuk hukuman lain yang bersifat mendidik, memberi efek jera agar murid tersebut tidak mengulanginya. Hukuman yang dilakukan oleh guru tersebut sering diartikan sama dengan tindakan kekerasan, penganiayaan, penyiksaan, dan tindakan yang tidak manusiawi oleh Orang Tua murid yang dimana hukuman tersebut berfungsi untuk memberikan efek jera kepada murid yang tidak menaati suatu aturan. ${ }^{1}$

Dalam Undang-Undang Nomor 39 Tahun 1999 tentang Hak Asasi Manusia diatur bahwa anak juga mempunyai hak dan kewajiban oleh karena hak dan kewajiban adalah satu hal yang tidak terpisahkan. Berdasarkan Undang-Undang Nomor 23 Tahun 2002 tentang Perlindungan Anak terdapat 5 (lima) hal kewajiban anak yang seharusnya dilakukan oleh seorang anak, yaitu:

a. Menghormati orang tua, wali, dan guru;

b. Mencintai keluarga, masyarakat dan menyayangi teman;

c. Menunaikan ibadah sesuai dengan keyakinan masing-masing;

d. Melaksanakan etika yang baik kepada masyarakat, orang tua, dan keluarga;

e. Melaksanakan peran serta masyarakat dalam hal berbangsa dan bernegara. ${ }^{2}$

Dengan demikian jelas bahwa anak atau murid wajib untuk menghormati guru karena guru adalah orang tua kedua di sekolah yang wajib untuk ditaati. Maraknya siswa yang saat ini semakin berani menentang aturan yang telah dibuat oleh sekolah atau mengabaikan perintah guru yang berdampak membuat guru tersebut emosi dan tanpa sengaja melakukan perbuatan-perbuatan yang seharusnya tidak dilakukan oleh guru tersebut. Sopan santun murid terhadap guru pada saat ini mengalami penurunan, terbukti ketika murid diingatkan oleh guru karena berbuat salah maka murid tersebut berani melawan guru dan juga menghina guru tersebut sehingga menimbulkan pertikaian antara murid dan guru.

Sejak Undang-Undang Nomor 23 Tahun 2002 tentang Perlindungan Anak diundangkan oleh Pemerintah Republik Indonesia maka sejak saat itu adanya pemberian hukuman terhadap anak di sekolah cenderung di salah artikan sebagai tindak kekerasan yang melukai murid.

\footnotetext{
${ }^{1}$ Nanang Martono, Kekerasan Simbolik di Sekolah Sebuah Ide Sosiologi Pendidikan Pierre Bourdieu, (Penerbit PT.RajaGrafindo Persada, Jakarta 2012).[1].

${ }^{2}$ Setya Wahyudi, Implementasi Ide Diversi Dalam Pembaharuan Sistem Peradilan Pidana Anak Indonesia, (Genta Publishing, Yogyakarta, 2011).[26].
} 
Contoh kasus tentang tindakan guru yang memberikan hukuman/sanksi kepada murid di salah artikan sebagai tindak kekerasan. Salah satu guru Sekolah Menengah Pertama di Kabupaten Bantaeng di tahan atas tuduhan melakukan kekerasan fisik terhadap anak didiknya. ${ }^{3}$

Pasal 80 Undang-Undang Nomor 35 Tahun 2014 Atas Perubahan Undang-Undang Nomor 23 Tahun 2002 tentang Perlindungan Anak yang sering digunakan untuk menjerat guru yang melakukan kekerasan terhadap siswa.. Kondisi tersebut menyebabkan posisi guru menjadi pasif dalam menjalankan tugas keprofesiannya. Sehingga guru cenderung melakukan pembiaran terhadap murid yang melakukan pelanggaran. Hal ini berakibat kepada sikap, perilaku, dan moral seorang murid dalam kesehariannya seperti murid yang berani melawan guru bahkan murid yang tidak takut pada apapun dalam kesehariannya.

Tindakan pendisiplinan yang dilakukan oleh guru terhadap murid dipengaruhi beberapa faktor dari guru maupun murid itu sendiri, misalnya tekanan kerja oleh guru, keadaan keluarga dari guru maupun murid, serta kurangnya komunikasi antara guru dan Orang Tua murid terhadap perilaku atau tindakan murid selama proses belajar mengajar. Tindakan tersebut tidak terlepas dari tata krama, etika dan sopan santun murid terhadap guru yang dapat memicu guru melakukan pendisiplinan secara spontan seperti menampar, mencubit, dan sejenisnya.

Perlindungan secara khusus yang diberikan oleh hukum terhadap profesi guru, secara jelas tercantum dalam Pasal 39 Undang-Undang Nomor 14 Tahun 2005 tentang Guru dan Dosen, menyebutkan bahwa:

1. Pemerintah, pemerintah daerah, masyarakat, organisasi profesi, dan/atau satuan pendidikan wajib memberikan perlindungan terhadap guru dalam pelaksanaan tugas.

2. Perlindungan sebagaimana dimaksud pada ayat (1) meliputi perlindurrgan hukum, perlindungan profesi, serta perlindungan keselamatan dan kesehatan kerja.

\footnotetext{
${ }^{3}$ Idris Apandi 'Guru Dalam Sanderaan Undang-Undang Perlindungan Anak' https://www. kompasiana.com/idrisapandi/guru-dalam-sanderaan-undang-undang-perlindungan-anak_574007b33cafbdd60e3a4caa diakses pada tanggal 2 Februari 2018 Pukul 09:45AM.
} 
3. Perlindungan hukum sebagaimana dimaksud pada ayat (2) mencakup perlindungan hukum terhadap tindak kekerasan, ancaman, perlakuan diskriminatif, intimidasi, atau perlakuan tidak adil dari pihak peserta didik, orang tua peserta didik, masyarakat, birokrasi, atau pihak lain.

4. Perlindungan profesi sebagaimana dimaksud pada ayat (2) mencakup perlindungan terhadap pemutusan hubungan kerja yang tidak sesuai dengan peraturan perundangundangan, pemberian imbalan yang tidak wajar, pembatasan dalam menyampaikan pandangan, pelecehan terhadap profesi, dan pembatasan/pelarangan lain yang dapat menghambat guru dalam melaksanakan tugas.

5. Perlindungan keselamatan dan kesehatan kerja sebagaimana dimaksud pada ayat (2) mencakup perlindungan terhadap risiko gangguan keamanan kerja, kecelakaan kerja, kebakaran pada waktu kerja, bencana alam, kesehatan lingkungan kerja, dan/atau risiko lain.

Dari ketentuan pasal 39 Undang-Undang Nomor 14 Tahun 2005 tentang Guru dan Dosen dijelaskan bahwa perlindungan Guru sudah diatur sedemikian rupa, sehingga apabila aturan tersebut dilaksanakan dengan baik maka guru akan dapat melaksanakan tugas profesinya dengan nyaman dan terbebas dari berbagai bentuk ancaman dan ketakutan.

Dalam Pasal 39 ayat (3) Undang-Undang Nomor 14 Tahun 2005 juga dijelaskan bahwasanya guru mendapatkan posisi yang eksklusif. Hal ini tidaklah berlebihan mengingat penanganan yang berlarut-larut atas tidak kekerasan, ancaman, diskriminatif yang diterima/ dialami guru. Hal tersebut juga berdampak pada terhambatnya guru dalam melaksanakan tugasnya sebagai pendidik. Meningkatnya berbagai permasalahan yang menimpa guru telah menyudutkan kehormatan profesi guru. Tindakan-tindakan guru pada murid dalam rangka mendidik serta menegakkan kedisiplinan terhadap murid terkadang dianggap salah oleh orang tua murid dan dianggap sebagai suatu bentuk perbuatan yang tidak termaafkan sehingga harus diselesaikan dengan tindak kekerasan dan bahkan ke meja hijau/pengadilan. Kondisi ini kemudian dimanfaatkan sekelompok orang dari bidang lain untuk mendapatkan keuntungan pribadi dengan melakukan "blow up" secara besar-besaran melalui berbagai media.

1. Apakah perbuatan guru dalam mendisiplinkan murid yang dapat berimplikasi tindak pidana?

2. Bagaimana pertimbangan hakim terkait tindakan guru terhadap murid yang berimplikasi terhadap tindak pidana? 


\section{Metode Penelitian}

Dalam penyusunan skripsi ini, penulis menggunakan salah satu tipe penelitian yaitu penelitian yuridis normatif, maksud dari secara yuridis adalah bahwa penelitian ini menelaah peraturan perundang-undangan, teori-teori, atau pendapat ahli hukum yang berkaitan dengan materi penulisan yang akan dibahas. Sedang tipe penelitian secara normatif maksudnya adalah menguraikan norma pasal, undang-undang yang berlaku dan pendapat ahli. Dengan kata lain penelitian yuridis normatif, yaitu metode penelitian berdasarkan dari berbagai peraturan perundang-undangan yang terkait dengan isu hukum dalam penelitian ini untuk menjawab isu hukum tersebut. Dalam penelitian ini menganalisa perlindungan guru terkait tindakan yang dilakukan oleh murid yang melakukan kenakalan yang dikaitkan dengan peraturan perundang-undangan yang berlaku.

\section{Perbuatan guru dalam mendisiplinkan murid yang dapat berimplikasi tindak pidana}

Guru tidak hanya dibutuhkan murid diruang kelas, tetapi juga diperlukan masyarakat lingkungannya dalam menyelesaikan aneka ragam permasalahan yang dihadapi masyarakat. Masyarakat menempatkan guru pada posisi terhormat dalam kehidupan masyarakat, yakni di depan memberi tauladan, ditengah-tengah membangun, dan di belakang memberi dorongan dan motivasi. ${ }^{4}$ Guru bagian dari sebuah mesin besar pendidikan nasional dan karena itu guru terikat pada ramburambu yang telah ditetapkan secara nasional mengenai apa yang mesti dilakukannya. ${ }^{5}$

Dalam Pasal 40 Peraturan Pemerintah Republik Indonesia Nomor 74 Tahun 2008 tentang Guru menjelaskan:

1. Guru berhak mendapat perlindungan dalam melaksanakan tugas dalam bentuk rasa aman dan jaminan keselamatan dari Pemerintah, Pemerintah Daerah, satuan pendidikan, Organisasi Profesi Guru, dan/atau Masyarakat sesuai dengan kewenangan masing-masing.

\footnotetext{
${ }^{4}$ Moh. Uzer Usman, Menjadi Guru Profesional (Remaja Rosdakarya1992).[5].

${ }^{5}$ Dedi Supriadi, Mengangkat Citra dan Martabat Guru (Adicita Karya Nusa 1999).[97].
} 
2. Rasa aman dan jaminan keselamatan dalam melaksanakan tugas sebagaimana dimaksud pada ayat (1) diperoleh Guru melalui perlindungan:

a. Hukum;

b. Profesi;

c. Keselamatan dan kesehatan kerja;

d. Masyarakat, Organisasi Profesi Guru, Pemerintah atau Pemerintah Daerah dapat saling membantu dalam memberikan perlindungan sebagaimana dimaksud pada ayat (1).

Dalam pasal ini dijelaskan bahwa guru berhak untuk mendapatkan perlindungan ketika menjalankan tugasnya yang dimana bentuk perlindungan tersebut berupa rasa aman dan jaminan keselamatan dari pemerintah maupun dari masyarakat tersebut. Rasa aman dan jaminan tersebut bisa diperoleh guru melalui perlindungan hukum yang selama ini sangat dibutuhkan oleh guru ketika guru tersebut harus berhadapan dengan hukum karena memberikan sanksi kepada murid yang ingin memberikan efek jera dan tidak bermaksud untuk melukai murid tersebut tetapi malah membuat guru tersebut berhadapan dengan hukum Pada Pasal 41 ayat (1) menjelaskan:

1. Guru berhak mendapatkan perlindungan hukum dari tindak kekerasan, ancaman, perlakuan diskriminatif, intimidasi, atau perlakuan tidak adil dari pihak peserta didik, orangtua peserta didik, Masyarakat, birokrasi, atau pihak lain.

Pada Pasal 39 Undang-Undang Nomor 14 Tahun 2005 tentang Guru dan Dosen menjelaskan:

1. Pemerintah, pemerintah daerah, masyarakat, organisasi profesi, dan/atau satuan pendidikan wajib memberikan perlindungan terhadap guru dalam pelaksanaan tugas.

2. Perlindungan sebagaimana dimaksud pada ayat (1) meliputi perlindungan hukum, perlindungan profesi, serta perlindungan keselamatan dan kesehatan kerja.

3. Perlindungan hukum sebagaimana dimaksud pada ayat (2) mencakup perlindungan hukum, perlindunganprofesi, serta perlindungan keselamatan dan kesehatankerja.

4. Perlindungan profesi sebagaimana dimaksud pada ayat (2) mencakup perlindungan terhadap pemutusan hubungan kerja yang tidak sesuai dengan peraturan perundang-undangan, pemberian imbalan yang tidak wajar, pembatasan dalam menyampaikan pandangan, pelecehan terhadap profesi, dan pembatasan/pelarangan lain yang dapat menghambat guru dalam melaksanakan tugas.

5. Perlindungan keselamatan dan kesehatan kerja sebagaimana dimaksud pada 
ayat (2) mencakup perlindungan terhadap risiko gangguan keamanan kerja, kecelakaan kerja, kebakaran pada waktu kerja, bencana alam, kesehatan lingkungan kerja, dan/atau risiko lain.

Dalam proses pembelajaran di kelas sering kali guru dihadapkan kepada Undang-Undang Nomor 23 Tahun 2002 Jo. Nomor 35 Tahun 2014 tentang Perlindungan Anak yang memberikan hak anak untuk diperlakukan dan dilindungi agar dapat hidup, tumbuh dan berkembang dan berpartisipasi secara optimal sesuai dengan harkat dan martabat kemanusiaan, serta mendapat perlindungan dari kekerasan dan diskriminasi. Terdapat sebagian murid yang lebih menonjol kenakalannya daripada kesadaran dalam proses belajar sehingga guru harus melakukan tindakan pendisiplinan agar timbul kesadarannya dalam proses belajar. Dalam melakukan tindakan terhadap murid, guru harus memenuhi tiga syarat yakni:

1. Dalam kondisi terpaksa;

2. Penderaan secara terbatas (harus dengan pertimbangan-pertimbangan tertentu); dan

3. Dipergunaan untuk mencapai tujuan-tujuan yang diperkenankan.

Dalam hal ini, guru dituntut agar sabar dalam mendidik murid-murid. Apabila dilihat dari aspek hukum pidana, perbuatan yang dilakukan guru terhadap murid berupa memarahi atau memberi teguran, memberi hukuman seperti menjewer, menyuruh berdiri, memukul dan lain-lain, secara formil bersifat melawan hukum atau juga bisa merupakan tindak pidana tetapi dalam hukum pidana tidak selalu orang yang secara formal telah melakukan tindakan melawan hukum harus dipidana. Tidak semua tindakan guru yang bersifat represif terhadap murid merupakan tindak pidana.

Dalam ketentuan hukum pidana alasan yang dapat menghapuskan pidana atau alasan yang tidak dapat dipertanggung jawabkan seseorang (terdakwa) karena yang terletak diluar orang itu (uitwendig), yaitu:

1. Pasal 48 KUHP tentang adanya daya paksa (overmacht)

2. Pasal 49 KUHP tentang pembelaan terpaksa (noodweer)

3. Pasal 50 KUHP tentang ketentuan undang-undang

4. Pasal 51 KUHP tentang melaksanakan perintah jabatan 
Dari uraian tersebut maka ada 3 alasan yang dapat menghapus proses hukum bagi seseorang (terdakwa) yang telah melakukan perbuatan melawan hukum, yaitu: ${ }^{6}$

1. Alasan Pembenar, yaitu alasan yang menghapuskan sifat melawan hukumnya perbuatan, sehingga apa yang dilakukan oleh terdakwa lalu menjadi perbuatan yang patut dan benar.

2. Alasan Pemaaf, yaitu alasan yang menghapuskan kesalahan terdakwa. Perbuatan yang dilakukan oleh terdakwa tetap bersifat melawan hukum jadi merupakan perbuatan pidana, tetapi tidak dipidana, karena tidak ada kesalahan.

3. Alasan menghapus penuntutan. Alasan menghapus penuntutan tidak dikarenakan adanya alasan pembenar atau pemaaf, jadi tidak ada pikiran mengenai sifatnya perbuatan maupun sifatnya orang yang melakukan perbuatan, namun pemerintah dengan alasan pertimbangan untuk kepentingan dan/atau manfaat umum sehingga tidak dilakukan atau menghapus penuntutan.

Menurut Memorie van Toelichting mengenai pembentukan Pasal 48 KUHP tersebut, overmacht itu disebut sebagai suatu "uitwendige oorzaak van ontoerekenbaarheid" atau sebagai suatu "penyebab yang datang dari luar yang membuat sesuatu perbuatan itu menjadi tidak dapat dipertanggungjawabkan kepada pelakunya" dan telah dirumuskan sebagai "elke kracht, elke dwang, elke drang, waaraan men geen weerstand kan bleden" atau " setiap kekuatan, setiap paksaan,setiap tekanan, di mana terhadap kekuatan, paksaan atau tekanan tersebut orang tidak dapat memberikan perlawanan". ${ }^{7}$

Dalam keadaan seperti itu, Profesor van HAMEL berpendapat bahwa overmacht itu bukan merupakan suatu :rechtvaardigingsgrond" atau suatu "dasar pembenaran" bagi apa yang telah dilakukan oleh seseorang, dan bukan pula merupakan keadaan yang meniadakan "hal yang dapat dipertanggungjawabkannya seseorang atas perbuatannya". Suatu "absolute oevrmacht" itu hanyalah menjadi tidak dapat dipertanggungjawabkan menurut hukum pidana, oleh karena perbuatan tersebut sebenarnya bukamlah merupakan perbuatan dari pelakunya sendiri. ${ }^{8}$

${ }^{6}$ Moeljatno, Asas-Asas Hukum Pidana (Rineka Cipta, Jakarta, 2008).[148].

${ }^{7}$ P.A.F. Lamintang, Dasar-Dasar Hukum Pidana Indonesia (Citra Aditya Bakti, Bandung, 2013).[148].

8 ibid.[430]. 
Sedang paksaan secara psikis itu dapat dipandang sebagai absolute dwang, yaitu apabila paksaan tersebut mempunyai pengaruh yang demikian besar pada susunan syaraf (zenuwstelsel) dari orang yang mendapat paksaan, hingga kemampuan dari orang itu sendiri menjadi tidak ada sama sekali. ${ }^{9}$

Terdapat beberapa pendapat didalam hukum pidana mengenai dasar-dasar yang meniadakan hukuman yang tidak diatur didalam undang-undang yang terpenting antara lain: ${ }^{10}$

a) Tindakan-tindakan penghukuman yang didasarkan pada hak mendidik oleh para orang tua, wali murid, para guru dan pendidik lainnya;

b) Tindakan-tindakan yang bersumber pada hak jabatan oleh para dokter, ahli-ahli apotek, ahli-ahli kebidanan dan lain-lain;

c) Tindakan-tindakan yang telah mendapat persetujuan terlebih dahulu dari pihak-pihak yang dirugikan dalam peristiwa-peristiwa tertentu;

d) Tindakan-tindakan yang didasarkan pada lembaga "zaakwaarneming" sebagaimana yang dimaksud didalam pasal 1354 dan selanjutnya dari Burgelijk Wetboek;

e) Tidak adanya "mateerieel wederrechtelujkheid" atau tidak adanya unsur melanggar hukum secara material pada sesuatu tindakan;

f) Tidak adanya sesuatu unsur schuld (avas) pada seseorang.

Dalam pendapat diatas tindakan yang dilakukan guru untuk mendisiplikan murid dapat diartikan bukan sebagai bentuk perbuatan tindak pidana. Pendapat ini dapat dijadikan sebagai suatu bentuk perlindungan pada guru yang tidak diatur dalam Kitab Undang-Undang Hukum Pidana.

Dalam islam juga mengatur batas-batas dalam mendidik seorang anak,yaitu: ${ }^{11}$

1. Larangan Memukul Wajah;

2. Larangan Untuk Menampakkan Emosi yang Berlebih atau Kemarahan Tidak Terkontrol;

3. Memukul dalam Keadaan Sangat Marah;

4. Bersikap Terlalu Keras dan Kasar;

5. Memukul dengan Benda Keras dan Berbekas di Badan Anak.

${ }^{11}$ Pusat Ilmu Islam Nusantara 'Hukum Memukul Anak Dalam Islam Dan Dalilnya' https:// dalamislam.com/hukum-islam/anak/hukum-memukul-anak-dalam-islam diakses pada Tanggal 22 Juni 2018, Pukul: 13.12.
} 
Dalam melakukan hukuman terhadap murid, guru harus menjaga batasan-batasan agar tindakan yang diberikan guru terhadap murid tidak berdampak lebih buruk bagi murid. Definisi kekerasan dalam dunia pendidikan adalah hukuman yang terasa keras bagi murid sehingga merasakan sakit, namun hukuman dalam dunia pendidikan seharusnya memberikan kesadaran agar murid tidak mengulangi kesalahannya lagi, istilah kekerasan ini berbeda konteks dengan hukuman fisik. Hukuman fisik (bisa berarti push-up, lari keliling lapangan, membersihkan atau menyapu perpustakaan) diperbolehkan dalam konteks pendidikan dan sebaiknya disepakati bersama oleh guru dan murid serta diinformasikan juga pada orang tua.

R. Soesilo mengatakan bahwa delik terdiri dari Delik Hukum (rechtsdelict) yaitu perbuatan yang bertentangan dengan asas-asas hukum positif dimana setiap orang akan menyatakan sebagai perbuatan kejahatan. Delik Undang-Undang (wetsdelict) yaitu perbuatan peristiwa pidana yang kecil. ${ }^{12}$

\section{Pertimbangan hakim terkait tindakan guru terhadap murid yang berimplikasi terhadap tindak pidana}

\section{Putusan Pengadilan Negeri Bulukumba Nomor: 122/PID.B/2013/PN.BLK}

Memutuskan bahwa Drs. H. Alamsyah Alias Alam Bin Jemma, tidak terbukti secara sah dan meyakinkan bersalah melakukan tindak pidana "Penganiayaan terhadap anak". Awalnya Drs. H. Alamsyah Alias Alam Bin Jemma dikenai Pasal 80 ayat (1) UU Nomor 23 Tahun 2002, yang unsur-unsurnya adalah sebagai berikut:

a. Setiap orang;

b. Menempatkan, membiarkan, melakukan, menyuruh melakukan, atau turut serta melakukan kekerasan terhadap anak;

Kejadian yang diduga penganiayaan yang dilakukan oleh guru terhadap siswa tersebut dilakukan pada tanggal 27 Mei 2013 oleh karena itu Drs. H. Alamsyah Alias Alam Bin Jemma dihukum dengan Pasal 80 ayat (1) Undang-Undang Nomor 23 Tahun 2002 tentang Perlindungan Anak. Unsur "menempatkan, membiarkan, [19].

${ }^{12}$ R.Soesilo, Pokok-Pokok Peraturan Umum dan Delik-Delik Khusus (Politeia, Bogor, 2014). 
melakukan, menyuruh melakukan, atau turut melakukan kekerasan terhadap anak" tidak terbukti karena Terdakwa tidak menggunakan alat tetapi menggunakan tangan kanan yang bertujuan untuk mendisiplinkan siswa tersebut yang berusaha kabur pada saat mata pelajaran.

Bila terdakwa berniat melukai siswa tersebut maka terdakwa tidak akan menyuruh Ketua Kelas untuk memanggil siswa yang berusaha untuk kabur dalam mata pelajaran tetapi terdakwa langsung menghampiri siswa tersebut. Dalam hal ini, Terdakwa berusaha untuk memberi teguran kepada siswa tersebut melalui Ketua Kelas tetapi diabaikan sehingga dengan terpaksa terdakwa turun tangan untuk memanggil siswa tersebut. Dalam hal ini, tindakan terdakwa termasuk dalam kategori pendisiplinan siswa bukan untuk melakukan kekerasan yang bertujuan untuk melukai siswa tersebut. Disamping itu terdakwa tersebut juga tidak menggunakan alat bantu apapun ketika memanggil siswa tersebut sehingga tuduhan yang diberikan kepada terdakwa tidak memenuhi syarat. Oleh karena itu putusan hakim membebaskan terdakwa sudah tepat karena perbuatan terdakwa bukan merupakan tindak pidana namun suatu tindakan untuk mendisiplikan muridnya yang tidak patuh terhadap perintah gurunya (terdakwa).

\section{Putusan Pengadilan Negeri Prabumulih Nomor: 44/Pid.Sus/2015/PN.Pbm}

Memutuskan bahwa Ngatijo Bin Harjodimulyo, terbukti secara sah dan meyakinkan bersalah melakukan tindak pidana "Penganiayaan terhadap anak". Ngatijo dikenai Pasal 80 ayat (1) Undang-undang Nomor 35 Tahun 2014, dan Ngatijo dijatuhi pidana penjara selama 5 (lima) bulan, Menetapkan pidana tersebut tidak perlu dijalani, kecuali jika dikemudian hari ada putusan Hakim yang menentukan lain disebabkan karena Terdakwa melakukan tindak pidana sebelum berakhirnya masa percobaan selama 10 (sepuluh) bulan. Ngatijo Bin Harjodimulyo dijatuhi dengan Pasal 80 ayat (1) UU Nomor 35 Tahun 2014, yang unsur-unsurnya adalah sebagai berikut:

a. Setiap orang;

b. Menempatkan, membiarkan, melakukan, menyuruh melakukan, atau turut serta melakukan kekerasan terhadap anak. 
Kejadian penganiayaan yang dilakukan oleh guru terhadap siswa tersebut dilakukan pada tanggal 20 Nopember 2014. Oleh karena itu Ngatijo Bin Harjodimulyo dihukum dengan Pasal 80 ayat (1) Undang-Undang Nomor 35 Tahun 2014 tentang perubahan Undang-Undang Nomor 23 Tahun 2002 tentang Perlindungan Anak. Pada Putusan Nomor 44/Pid.Sus/2015/PN.Pbm Ngatijo dihukum karena telah memukul siswa tersebut sehingga mengenai bawah matanya. Namun maksud Terdakwa hanya ingin memukul bahu kanan siswa tersebut tetapi diluar dugaan siswa tersebut memalingkan wajahnya sehingga mistar kayu mengenai bawah mata siswa tersebut. Dalam hal ini Terdakwa hanya ingin memberikan efek jera kepada siswa yang melakukan kegaduhan sehingga mengganggu konsentrasi siswa lainnya, sebelum Terdakwa memukul siswa tersebut sudah di dahului dengan memberikan peringatan selama 3 kali tetapi siswa tersebut mengabaikan peringatan yang diberikan oleh Terdakwa.

Dalam hal ini, disiplin sekolah diperlukan yaitu bertujuan untuk membantu peserta didik menemukan jati dirinya, mengatasi dan mencegah timbulnya kemungkinan terjadinya problem-problem dalam kehidupan. Disiplin yang dalam hal ini adalah mengganggu siswa lain dalam menerima pelajaran di sekolah, serta berusaha menciptakan situasi yang menyenangkan dalam pembelajaran sehingga mereka menaati segala peraturan yang ditetapkan. Disiplin sekolah termasuk bantuan kepada peserta didik agar mereka mampu berdiri sendiri sehingga dapat memecahkan masalah guna mendapat hasil belajar yang optimal dengan proses yang menyenangkan. ${ }^{13}$

Menurut T.Hani Handoko menyatakan bahwa disiplin mempunyai tiga macam sifat, yaitu:

1. Disiplin preventif;

2. Disiplin korektif dan;

3. Disiplin progresif.

Disiplin preventif adalah tindakan Sumber Daya Manusia (SDM) yang

${ }^{13}$ E. Mulyasa, Implementasi Kurikulum Tingkat Satuan Pendidikan Kemandirian Guru dan Kepala Sekolah ( Jakarta, Bumi Aksara, 2009).[191-192]. 
terdorong untuk mentaati standar dan peraturan. Tujuan pokoknya adalah mendorong SDM agar memiliki disiplin pribadi yang tinggi agar peran kepemimpinan tidak terlalu berat dengan pengawasan atau pemaksaan yang dapat mematikan prakarsa dan kreativitas serta partisipasi SDM. Disiplin korektif adalah tindakan yang dilakukan setelah terjadi pelanggaran standar atau peraturan, tindakan tersebut dimaksudkan untuk mencegah timbulnya pelanggaran lebih lanjut. Berupa hukuman tertentu atau tindakan disipliner, antara lain berupa peringatan, skors, dan pemecatan. Disiplin progresif adalah tindakan disipliner berulang-ulang berupa hukuman yang makin berat, dengan maksud agar pihak pelanggar bisa memperbaiki diri sebelum hukuman berat dijatuhkan. ${ }^{14}$

Dalam hal ini, Terdakwa melakukan disiplin korektif yang dimana adanya tindakan yang dilakukan setelah terjadi pelanggaran standar atau peraturan yang telah ditetapkan oleh sekolah yang dimana siswa selama dalam jam pelajaran tidak boleh melakukan keributan atau kegaduhan yang menyebabkan terganggunya proses belajar mengajar tetapi didahului dengan teguran yang diabaikan oleh siswa tersebut.

Perbuatan Terdakwa menjadi memberatkan Terdakwa karena menggunakan alat untuk memukul siswa tersebut yaitu mistar kayu yang mengakibatkan luka di daerah bawah mata sehingga Hakim menjatuhkan hukuman kepada Terdakwa dengan pidana penjara selama 5 (lima) bulan dengan masa percobaan selama 10 (sepuluh) bulan. Bila ingin menjatuhkan hukuman kepada guru yang melakukan tindakan disiplin bagi siswa harus memperhatikan beberapa aspek termasuk kenapa guru tersebut harus terpaksa melakukan tindakan. Tindakan yang dilakukan terdakwa hanya untuk melakukan pendisiplinan agar siswa tersebut patuh terhadap aturan didalam proses pendidikan. Hukuman yang dijatuhkan oleh hakim seharusnya wajib menggali, mengikuti, dan memahami nilai-nilai hukum dan rasa keadilan yang hidup dalam masyarakat diatur dalam Undang-Undang No.48 tahun 2009 tentang Kekuasaan Kehakiman.

${ }^{14}$ T.Hani Handoko, manajemen Personalia \& Sumber Daya Manusia (Yogyakarta, BPFE UGM Persada 2010).[209-2011]. 


\section{Putusan Pengadilan Negeri Kayuagung Nomor: 345/Pid,Sus/2015/PN.Kag}

Memutuskan bahwa Hj. Ruslaini binti H.Hasyim, terbukti secara sah dan meyakinkan bersalah melakukan tindak pidana "Penganiayaan terhadap anak". Hj. Ruslaini dikenai Pasal 80 ayat (1) Undang-undang Nomor 35 Tahun 2014. Terdakwa Hj. Ruslaini dijatuhkan pidana penjara selama 4 bulan dan denda sebesar Rp.10.000.000,- dengan ketentuan apabila pidan denda tersebut tidak dibayar diganti dengan pidana kurungan selama 1 bulan. Menentapkan pidana tersebut tidak perlu dijalankan, terkecuali apabila dikemudian hari sebelum berakhirnya masa percobaan selama 8 bulan terdakwa telah dipersalahkan telah melakukan suatu tindak pidana, dan membebankan terdakwa membayar biaya perkara sebasar Rp. 2000,-.

Hj. Ruslaini binti H. Hasyim dijatuhi dengan Pasal 80 ayat (1) UU Nomor 35 Tahun 2014, yang unsur-unsurnya adalah sebagai berikut:

a. Setiap orang;

b. Menempatkan, membiarkan, melakukan, menyuruh melakukan, atau turut serta melakukan kekerasan terhadap anak;

Kejadian penganiayaan yang dilakukan oleh guru terhadap siswa tersebut dilakukan pada tanggal 16 Januari 2015 pukul 07.30. Oleh karena itu Hj. Ruslaini binti H. Hasyim dihukum dengan Pasal 80 ayat (1) Undang-Undang Nomor 35 Tahun 2014 tentang perubahan Undang-Undang Nomor 23 Tahun 2002 tentang Perlindungan Anak. Pada Putusan Nomor: 345/Pid.Sus/2015/PN Kag Hj.Ruslaini dihukum karena telah melakukan pemukulan terhadap siswa yang mengakibatkan luka lecet di ruas jari tangan kanan. Hal ini disebabkan karena kuku siswa tersebut terlihat kotor, dalam hal ini perbuatan terdakwa sebagai guru dilakukan atas dasar tujuan yang mulia, terdakwa ingin membentuk siswa yang mempunyai displin tinggi dalam rangka mendidik tidak bertujuan untuk mendatangkan rasa sakit. Tindakan yang dilakukan terdakwa sebagai seorang guru semata-mata hanya untuk memberikan efek jera bagi murid dalam proses pembelajaran agar tidak mungulanginya lagi, hal ini sesuai dengan tujuan pendidikan nasional untuk mencerdaskan kehidupan bangsa yang termaktub dalam pembukaan Undang-Undang Dasar Republik Indonesia tahun 1945 alenia ke 4. Jabaran UUD 1945. 


\section{Kesimpulan}

Dalam menjalankan tugasnya Guru diberikan kewenangan untuk memberikan tindakan dalam rangka mendisiplikan murid yang melanggar peraturan sekolah yang telah disepakati. Terdapat beberapa murid yang lebih menonjol kenakalannya sehingga guru harus melakukan tindakan pendisiplinan. Dalam hal ini Guru tersebut mempertimbangkan banyak aspek sebelum melakukan tindakan pendisiplinan. Sebelum dilakukan tindakan pendisiplinan itu dilakukan diawali dengan teguran selama beberapa kali sehingga ketika teguran tersebut diabaikan maka pada akhirnya dengan terpaksa dilakukan suatu tindakan (fisik).

Dalam 3 (tiga) kasus putusan pengadilan tersebut, Guru sudah berupaya melakukan teguran selama beberapa kali tetapi teguran tersebut tidak dihiraukan oleh murid tersebut sehingga tindakan pendisiplinan dilakukan. Memang ada beberapa tindakan pendisiplinan tersebut menggunakan alat, namun dalam rangka proses pendisiplinan bukan bertujuan untuk melakukan kekerasan terhadap murid tersebut. Akibat hukum atas tindakan guru yang terlalu keras dalam mendisiplikan murid pada 3 kasus tersebut dikenakan Pasal 80 ayat (1) UU Nomor 35 Tahun 2014 tentang Perlindungan Anak.

\section{Daftar Bacaan}

\section{Buku}

Nanang Martono, Kekerasan Simbolik di Sekolah Sebuah Ide Sosiologi Pendidikan Pierre Bourdieu (Penerbit PT.RajaGrafindo Persada 2012).

Setya Wahyudi, Implementasi Ide Diversi Dalam Pembaharuan Sistem Peradilan Pidana Anak Indonesia (Genta Publishing 2011).

Moh. Uzer Usman, Menjadi Guru Profesional (Remaja Rosdakarya 1992).

Dedi Supriadi, Mengangkat Citra dan Martabat Guru (Adicita Karya Nusa 1999). Moeljatno, Asas-Asas Hukum Pidana (Rineka Cipta 2008).

P.A.F. Lamintang, Dasar-Dasar Hukum Pidana Indonesia (Citra Aditya Bakti 2013). 
E. Mulyasa, Implementasi Kurikulum Tingkat Satuan Pendidikan Kemandirian Guru dan Kepala Sekolah (Bumi Aksara 2009).

T.Hani Handoko, manajemen Personalia \& Sumber Daya Manusia (BPFE UGM Persada 2010).

\section{Laman}

Idris Apandi 'Guru Dalam Sanderaan Undang-Undang Perlindungan Anak'https:// www.kompasiana.com/idrisapandi/guru-dalam-sanderaan-undang-undangperlindungan-anak_574007b33cafbdd60e3a4caa diakses pada tanggal 2 Februari 2018 Pukul 09:45AM http://www.academia.edu/, diakses pada tanggal 25 April 2018, Pukul 11.30.

Pusat Ilmu Islam Nusantara 'Hukum Memukul Anak Dalam Islam Dan Dalilnya' https:/dalamislam.com/hukum-islam/anak/hukum-memukul-anak-dalamislam diakses pada Tanggal 22 Juni 2018, Pukul: 13.12.

\section{Perundang-undangan}

Undang-Undang Dasar Negara Republik Indonesia Tahun 1945.

Undang-Undang Nomor 1 Tahun 1946 tentang Peraturan Hukum Pidana juncto Undang-Undang Nomor 73 Tahun 1958 (Lembaran Negara Nomor 127 Tahun 1958, Tambahan Lembaran Negara Nomor 1660 tahun 1958) tentang menyatakan berlakunya Undang-Undang Nomor 1 tahun 1946 Republik Indonesia Tentang Peraturan Hukum Pidana untuk seluruh Wilayah Republik Indonesia dan Mengubah Undang-Undang Hukum Pidana.

Undang-Undang Nomor 20 tahun 2003 Tentang Sistem Pendidikan Nasional. (Lembaran Negara Tahun 2003 Nomor 78, Tambahan Lembaran Negara Nomor 4301).

Undang-Undang Nomor 14 Tahun 2005 tentang Guru dan Dosen (Lembaran Negara Tahun 2005 Nomor 157, Tambahan Lembaran Negara Nomor 4586).

Undang-Undang Nomor 48 Tahun 2009 tentang Kekuasaan Kehakiman (Lembaran Negara Tahun 2009 Nomor 157, Tambahan Lembaran Negara Nomor 5076).

Undang-Undang Nomor 35 Tahun 2014 tentang Perubahan Atas Undang-Undang Nomor 23 Tahun 2002 tentang Perlindungan Anak (Lembarana Negara Tahun 2014 Nomor 297, Tambahan Lembaran Negara Nomor 5606). 
Peraturan Pemerintah Republik Indonesia Nomor 74 Tahun 2008 tentang Guru.

Peraturan Menteri Pendidikan dan Kebudayaan Republik Indonesia Nomor 10 Tahun 2017 tentang Perlindungan Bagi Pendidik dan Tenaga Kependidikan.

HOW TO CITE: Alfin Ersa Ardiansyah, 'Perlindungan Guru Terkait Tindakan yang Dilakukan Pada Murid Yang Melakukan Kenakalan’ (2019) Vol. 2 No. 1 Jurist-Diction. 